\title{
AS PECULIARIDADES DO DISCURSO JURÍDICO: ALGUMAS CONSIDERAÇÕES
}

\author{
COMPARINI, Ana Maria Paulino ${ }^{1}$
}

\begin{abstract}
RESUMO: Este estudo faz parte de um projeto maior denominado A modalização deôntica no discurso jurídico, o qual busca o entendimento do universo de discurso do Direito, examinando a linguagem jurídica a partir da perspectiva da modalidade deôntica. O objetivo deste trabalho é promover uma reflexão acerca das peculiaridades que envolvem o discurso proferido no tribunal do júri. Para tanto, optou-se pelo levantamento, seleção e documentação de vasta bibliografia já publicada sobre o assunto, em livros, revistas e tratados em geral. Pode-se, então, concluir que o discurso jurídico caracteriza-se como um discurso normativo, deonticamente modalizado: por si só autoritário, que deixa claro o que é obrigatório, permitido e proibido fazer. Desse modo, fatores como as peculiaridades do próprio discurso compõem as condições de produção do discurso jurídico e constituem o processo de interação comunicativa dos tribunais, embora, muitas vezes, tais peculiaridades sejam vistas como um Manual de regras a serem seguidas.
\end{abstract}

Palavras-chave: Discurso normativo. Modalidade deôntica. Linguagem jurídica.

SUMMARY: This study is part of a larger project called The deontic modalization in the juridical speech, which seeks to understand the universe of Law Speech, examining the juridical language from the deontic modality perspective. The objective of this work is to promote a reflection about the peculiarities that surround the speech delivered in the jury court. In order to do so, we chose to collect, select and document a vast bibliography already published on the subject, in books, magazines and treatises in general. One can then concluded that, the legal speech is characterized as a normative speech, deontically modilized: bein authoritarian itself, making clear what is obligatory, allowed and prohibited to do. Thus, factors such as the peculiarities of the speech itself comprise the juridical speech production conditions and constitute the process of communicative interaction of courts, although, such peculiarities are often seen as a Manual of rules to be followed.

Keywords: Normative speech. Deontic modality. Juridical language.

\section{INTRODUÇÃO}

O Direito é considerado uma ciência, não uma arte, o que faz surgir a obrigatoriedade do uso de uma linguagem técnica e, consequentemente, a proibição de expressões vulgares, coloquiais ou gírias. O jurista possui a missão de contribuir para que a justiça se realize, e o uso adequado da palavra é uma de suas ferramentas mais importantes. Desse uso, muitas vezes, depende a vitória ou a derrota da causa defendida pelo jurista.

Cientes do poder das palavras, os juristas acabaram por desenvolver um discurso bastante peculiar, com regras próprias, que são ensinadas e reforçadas nos cursos de graduação de Direito de todo o país. Segundo Petri (2000, p.96), "as formas de discurso judiciário, muitas vezes, vêm estabelecidas na lei, por exemplo, nos Códigos de Processo Civil ou Penal, ou em leis extraordinárias que fixam o modo de procedimento, indicando até o conteúdo formal dos petitórios".

\footnotetext{
${ }^{1}$ FFCL / Unifran / Rede Estadual de Ensino de São Paulo
} 


\section{DISCURSO JURÍDICO}

O discurso jurídico caracteriza-se como um discurso normativo. Regras e normas são ensinadas e cobradas dos aspirantes a juristas como vitais para seu sucesso. Percebe-se que os próprios ensinamentos do Direito fazem uso de um discurso deonticamente modalizado, um discurso por si só autoritário, que deixa claro o que é obrigatório, permitido e proibido fazer. Palavras como: estabelecer, dever, ter que, é preciso, é necessário e poder são utilizadas em profusão nos ensinamentos jurídicos. Constata-se, inclusive, a existência de uma disciplina denominada Deontologia Jurídica que é considerada a doutrina dos valores éticos do Direito (REALE, 1996).

Uma análise do discurso jurídico, portanto, não pode prescindir da análise das orientações que trazem os inúmeros manuais de redação jurídica, utilizados pelos advogados-aprendizes. Um olhar sobre essas orientações e as coerções que elas impõem nos permitirá entender melhor as condições de produção do discurso jurídico.

A oratória forense foi, por muito tempo, usada com excesso de refinamento, rebuscamentos, adornos, pompa e minúcias formalistas, e ainda hoje, faz grande uso de termos latinos e expressões pouco inteligíveis ao leigo. De acordo com Martins (1998), o estilo forense deve ter como atributos a clareza, a precisão, a harmonia e a concisão. Azevedo (apud RIBEIRO, 1999, p.116) postula que tendo como funções argumentar e convencer, o orador deve evitar o uso da linguagem intrincada, peculiar ao Direito, pois "o uso desconexo de noções técnicas impede a comunicação entre o jurista e o povo, entrava as soluções e desmoraliza a profissão jurídica”.

Considerando que a linguagem é um meio de transmissão de ideias, entendem os juristas que quanto melhor for o meio, melhor será a transmissão. Eles argumentam que para alcançar seus objetivos, a comunicação no Direito terá de ser perfeita e, para isso, é preciso ter não só domínio das regras gramaticais como clareza e precisão de ideias. O Código de Processo Civil, em seu artigo 284, determina que o Juiz verifique "defeitos e irregularidades capazes de dificultar o mérito" (CAHALI, 1999, p.420). Essa exigência implica e envolve a linguagem, e a correção é tida como um pressuposto.

Os manuais que regem o discurso jurídico apontam que, para escrever e falar bem, além da organização lógica das ideias, do domínio das regras gramaticais e do vocabulário, é preciso usar corretamente instrumentos de persuasão e de expressividade do pensamento nos quais incluem as figuras de retórica que, segundo Nascimento (2013), requerem do usuário bom senso ao empregá-las. Os ensinamentos da Retórica ${ }^{2}$ aparecem no discurso do Direito mais como uma técnica de argumentação que de ornamentação. Falar bem abrange a fala elegante, agradável, com estilo e harmonia e a persuasão. Conclui Citelli (2004, p.32) que "o discurso persuasivo se dota de recursos retóricos objetivando o fim último de convencer ou alterar atitudes e comportamentos já estabelecidos”.

Além de todas as peculiaridades do discurso jurídico, que são passadas ao jurista ainda durante a sua formação acadêmica e que são vistas como um Manual de regras a serem seguidas, citamos, também, a questão da defesa oral. As instruções para se compor a defesa oral são as mesmas para a escrita de um texto dissertativo. De acordo com estas instruções, a defesa oral deve conter as três partes distintas: introdução, desenvolvimento (a exposição propriamente dita) e conclusão, e é preciso que o jurista se atenha com rigor e cuidado a cada uma delas a fim de obter o efeito desejado. Com o auxílio da retórica e da estilística, o jurista procura fazer uso da palavra não apenas para transmitir ou comunicar algo, mas, também, para convencer o interlocutor e conquistar sua adesão.

\footnotetext{
${ }^{2}$ Como arte de convencer pelo discurso, a Retórica era definida como uma ars bene dicendi, ou seja, uma arte do discurso eficaz, velha ciência da persuasão (ALLAN, 1983).
}

Nucleus,v.14,n.2,out.2017 
A defesa oral dos tribunais aparece regulada no Código de Processo Penal, nos art.610 e seguintes (GOMES, 2002), e para produzir tal defesa, há obrigatoriedade de que seja um advogado, não bastando um estagiário ou estudante. Na exposição oral, o momento da introdução vai ser utilizado pelo jurista não somente para apresentação do assunto a ser debatido. Esse momento é chamado de persuasão, pois é quando o orador busca se familiarizar com o auditório que o assiste (juiz, adversário, jurados e público); por meio de breve elocução ele se apresenta, cumprimenta os demais e deixa o auditório perceber que domina o assunto em questão. Segundo os ensinamentos do Direito, o orador não deve fazer uso de linguagem prolixa e nem descontraída demais. Aliando descontração e linguagem formal, o orador deixa o auditório mais à vontade e motivado para a exposição.

Ainda segundo as instruções recebidas pelos juristas, sem incorrer na vulgaridade ou no rebuscamento excessivo, o desenvolvimento da exposição deve ser feito de maneira clara, concisa, segura e com vigor pelo orador. $\mathrm{O}$ desenvolvimento das ideias deve obedecer a um plano previamente elaborado: os fatos devem ser desdobrados de maneira lógica ou mesmo cronológica, para que a apreensão da mensagem pelo auditório não se torne difícil ou enfadonha. A linguagem deve ser clara e precisa, espontânea, mas sem cair na vulgaridade; o uso de termos técnicos não pode exceder ou tomar contornos exagerados; o latinismo é tido como oportuno desde que usado com moderação, e as expressões estrangeiras devem, em sua maioria, ser seguidas de sua tradução.

Por fim os juristas são orientados quanto à exposição da conclusão. Nesse momento, o orador deve evitar a repetição de assuntos já abordados no desenvolvimento. A conclusão caracteriza-se por ser um resumo claro e conciso das ideias defendidas. Sem usar de tom melodramático, o orador deve deixar um apelo para uma reflexão por parte do auditório.

Ainda segundo Gomes (2002), o Código de Processo Penal, em seu art.474, estabelece que acusação e defesa dispõem de duas horas para sua exposição oral; estabelece, também, uma hora para a réplica e uma hora para a tréplica. Mas o orador deve ficar sempre atento em relação ao uso moderado e oportuno do tempo, pois o auditório pode sentir-se enfastiado ou acabar tendo dificuldades para acompanhar o raciocínio das ideias expostas.

Os oradores também são orientados a contar com outros recursos. Fagundes (1987) afirma que os recursos suprassegmentais, tais como as pausas e o tom de voz, constituem um recurso decisivo não só do discurso jurídico, como também, do discurso em geral. Argumentam Damião e Henriques (2015) que o jurista deve levar em conta não só a composição ou o conteúdo a ser desenvolvido, mas também os auxiliares da expressão oral: o timbre da voz, a altura da emissão vocal, a postura, o jogo rítmico do corpo, dos braços, da fisionomia, a entonação da frase, ou seja, traços paralinguísticos que caracterizam o ato oratório. No entanto, os autores ressaltam que é preciso saber utilizar-se deles. Alertam, ainda, que "a comunicação do corpo é operador funcional de suma importância como mediadora de 'leituras' interpretativas" (p.222). Cabe, portanto, ao orador saber dosar gestos, olhares, posturas e tom de voz para não incorrer no pedantismo ou no óbvio.

\subsection{Léxico e semântica}

Quanto ao vocabulário jurídico, ele é vastamente estudado no Direito. Alegam os juristas que seu uso amplia as chances de uma argumentação mais elaborada e convincente. A Semântica também surge na formação da linguagem jurídica, os sentidos conotativo e denotativo das palavras são largamente explorados, bem como a polissemia, a homonímia e a sinonímia.

Ainda na própria universidade, o aspirante a jurista é colocado em contato com longas listas de Brocardos Jurídicos (breve proposição que contém um princípio de direito ou regra de interpretação), 
listas de locuções latinas, prefixos e sufixos gregos e latinos e expressões mais usuais no Direito. São, também, orientados quanto à sintaxe e morfologia, pois é inadmissível que um jurista não tenha domínio de sua própria língua ou não faça uso correto da mesma.

O próprio caráter conservador da linguagem jurídica faz que os arcaísmos ainda sejam muito utilizados. Por outro lado, também, os neologismos, os estrangeirismos e os latinismos aparecem no discurso jurídico em profusão.

Concordando com Damião e Henriques (2015) ressaltamos, ainda, que o sistema jurídico necessita cuidar não só do valor nocional do vocabulário técnico, como também necessita estabelecer relações semântico-sintáticas que sejam harmônicas e seguras na construção do pensamento, e aqui vale salientar que o jurista precisa se ater a outras questões de igual relevância como a coesão e a coerência para que seu discurso torne-se interessante e consiga prender a atenção do auditório, não se esquecendo de que a ornamentação exagerada e sem critério desvia o orador do caminho da expressividade, clareza e inteligibilidade, o que torna o texto enfadonho e desagradável.

\subsection{Condições de produção do discurso jurídico}

Outros fatores externos ao texto propriamente dito também contribuem para a produção do discurso e, consequentemente, no resultado do julgamento. Dentre eles, podemos citar o próprio ambiente do Fórum onde réus, testemunhas, advogados, jurados e juiz se confrontam.

Num primeiro momento pode-se fazer referência ao ambiente que antecede o início do julgamento, e caracterizá-lo como aparentemente tranquilo, mas ao mesmo tempo, muito tenso. Enquanto aguardam o julgamento, as pessoas chamadas ao Fórum para participar da seleção dos jurados convivem lado a lado com advogados, familiares e amigos de vítimas e de réus, policiais armados e uma audiência mesclada de estudantes e interessados no assunto. Após a entrada do Juiz, dos advogados, e das demais pessoas que participarão da sessão (escrivão, policiais e trabalhadores do Fórum), acontece o sorteio para determinar quais serão os jurados que efetivamente participarão da sessão. Quando é feita a chamada para que o réu adentre a sala, verifica-se um encontro que reúne acusado e advogados na presença do Juiz. Esse encontro marca o início da sessão e é carregado de tensão.

Bezerra (1998) observa que outros elementos também influenciam para que o ambiente seja austero, como o posicionamento das pessoas que irão participar da sessão: a mesa ao fundo é utilizada pelo juiz que é ladeado pelo promotor à direita e o escrivão à esquerda; na mesa lateral direita do juiz fica o advogado de defesa, que tem à sua frente o réu ladeado por um policial; o corpo de jurados fica na lateral esquerda do juiz, de frente para o réu e o advogado de defesa. Essas posições fazem que advogados, réu e jurados se confrontem sem envolver aqueles que estão na platéia. O juiz, ao centro, é o mediador da situação. Outro elemento que denota seriedade e formalidade é o próprio traje utilizado pelos juristas para a sustentação oral: a beca preta, que é privativa dos advogados.

Todo o ambiente do Tribunal é bastante organizado e formal, o que nos deixa antever que nenhum dos discursos que serão proferidos ali poderá ser diferente. É óbvio que o grau de formalidade poderá variar, em função até da temática abordada, mas o próprio ambiente pede austeridade e, na linguagem dos juristas, reticências formais.

A questão do auditório também é abordada nos ensinamentos do Direito. De acordo com Perelman e Olbrechts-Tyteca (2000), a ideia de auditório é evocada imediatamente assim que se pensa num discurso. Os autores chamam de auditório o conjunto daqueles que o orador pretende influenciar, por meio de sua argumentação. 
Embora todo discurso seja organizado em função direta do auditório, ao elaborar o texto com o qual pretende persuadir um auditório, o orador não conhece o corpo de jurados, os quais, também, não se podem manifestar. Portanto, o orador não elabora seu discurso tendo em vista particularidades dos jurados, o que o leva à escolha de processos e estratégias argumentativas que façam com que o tema apreciado seja aceito por todos com unanimidade. A intenção é sempre uma só: por meio da interação, persuadir os jurados a absolver ou condenar o réu.

\section{MODELOS DE INTERAÇÃO E O DISCURSO JURÍDICO}

Considerando que a interação implica certo tipo de disputa, na medida em que os participantes são parceiros de um jogo, o da linguagem, o exame dessa relação, na qual atuam emissores e receptores, deverá nos mostrar seus respectivos posicionamentos em relação a seus discursos.

Segundo Osakabe (1979), analisar um discurso implica discorrer previamente sobre suas condições de produção a fim de que se possa fazer uma observação interna de cada realidade discursiva.

Relevantes na organização argumentativa do discurso, suas condições de produção expressam a interação social, ocorrida por meio da linguagem, entre emissor e receptor.

Ao enunciar os diferentes elementos estruturais das condições de produção do discurso, Pêcheux $(1969$, p.82) define destinador e destinatário como representantes de lugares determinados na estrutura de uma formação social, ou seja, no processo discursivo, o que funciona "é uma série de formações imaginárias que designam o lugar que A e B se atribuem cada um a si e ao outro, a imagem que eles fazem de seu próprio lugar e do lugar do outro". Para Pêcheux, discurso é a soma de linguagem e ideologia, em que todos os sentidos são influenciados pelo sujeito; esse jogo de imagens entre destinador e destinatário faz parte de todo processo discursivo.

Dik (1989) também aponta a língua como um instrumento de interação social que tem como objetivo principal o estabelecimento de relações comunicativas entre os usuários.

Assim, considerando o modelo de interação social por meio da linguagem desenvolvido por Dik (1989), podemos analisar as condições que envolvem a produção do discurso jurídico.

No processo de interação verbal os interlocutores consideram aspectos que interferem na construção do discurso, como, por exemplo, quem é o receptor e quais as informações pragmáticas de que dispõe, quais as intenções do emissor e quais informações pragmáticas de que dispõe, que estratégias utilizar a fim de se fazer entender e entender o outro e como levar o outro a cooperar no processo por meio de argumentação.

Ainda de acordo com Dik (1989), a interação social por meio da linguagem é uma forma de atividade cooperativa estruturada. É atividade estruturada porque é regida por normas, regras e convenções e é atividade cooperativa por necessitar de dois (ou mais) participantes a fim de atingir seus objetivos. As expressões linguísticas são os instrumentos usados por esses participantes durante a interação verbal e são, também, entidades estruturadas, regidas por regras e princípios que determinam sua construção.

O modelo de interação verbal proposto por Dik $(1989$, p.8) pode ser assim esquematizado: 
Figura 1: Modelo de interação verbal

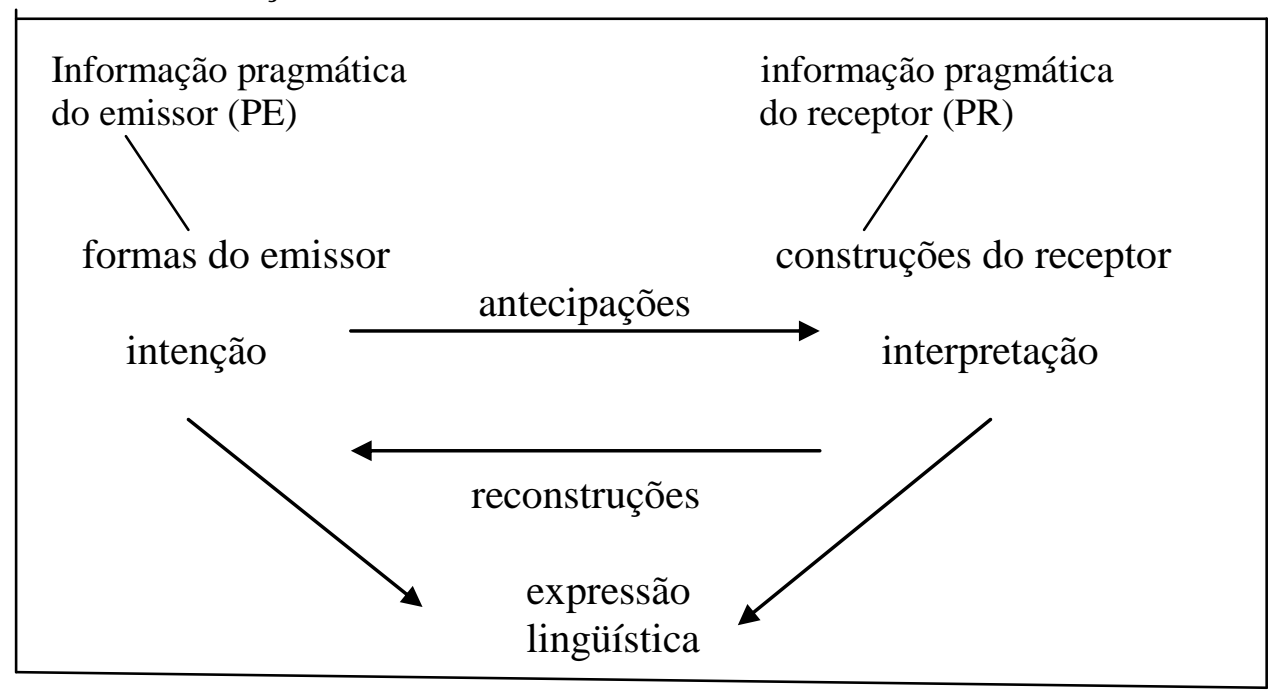

Fonte: Dik, 1989, p.8

A explicação e os comentários sobre esse esquema fornecido por Dik (1989, p.8-10) são aqui resumidos.

Segundo Dik, PE e PR são, respectivamente, a quantidade de informação pragmática ${ }^{3}$ de que dispõem o Emissor (E) e o Receptor (R). Ao dizer algo para R, E tem a intenção de efetuar algum tipo de modificação na informação pragmática de $\mathrm{R}$ (PR). Para isso, E deve ter algum tipo de intenção comunicativa a fim de conseguir a modificação que deseja causar em PR. E deve antecipar a possível interpretação que $\mathrm{R}$ atribuirá à sua expressão linguística, o que requer que $\mathrm{E}$ tenha um quadro razoável das partes relevantes de PR. Assim, uma avaliação de PR é parte de PE.

Por outro lado, $\mathrm{R}$ tenta chegar à reconstrução da presumida intenção comunicativa de $\mathrm{E}$, interpretando a expressão linguística de $\mathrm{E}$ à luz de sua informação pragmática e de sua avaliação da informação pragmática de E. Se a interpretação levar R à modificação em PR, isso corresponderá à intenção comunicativa de $\mathrm{E}$. Se $\mathrm{R}$ não alcançar uma interpretação que combine com a intenção comunicativa de $\mathrm{E}$, poderá haver um desentendimento.

A relação entre a intenção de $\mathrm{E}$ e a interpretação de $\mathrm{R}$ será mediada pela expressão linguística. Para $\mathrm{R}$ isso significa que a interpretação se baseará somente em parte na informação contida na expressão linguística como tal. Para E a expressão linguística não necessita ser uma verbalização completa de sua intenção.

E e R podem compartilhar informação pragmática, mas, também, é preciso levar em conta que existe a informação disponível apenas a $\mathrm{E}$ ou a $\mathrm{R}$ e, é justamente nessa informação não compartilhada que se localiza o ponto real da interação verbal que, no entanto, só pode ser identificado contra o pano de fundo da informação compartilhada.

E efetuar mudanças na informação pragmática de R é a função primária da interação verbal. E pode adicionar ou fornecer alguma informação de que R não dispunha; pode substituir a informação de R; pode lembrar a $\mathrm{R}$ de informações das quais ele não tenha consciência no momento e, $\mathrm{E}$ pode, até mesmo, efetuar mudanças na informação emocional de R.

Dik (1997), em outro texto de sua autoria, ressalta que esse modelo de comunicação verbal é, também, relevante para a produção e interpretação do discurso.

\footnotetext{
3 Informação Pragmática: "conjunto completo de conhecimento, crenças, assunções, opiniões e sentimentos disponíveis a um indivíduo em qualquer ponto da interação". ("The full body of knowledge, beliefs, assumptions, opinions, and feeling available to an individual at any point in the interaction”) (DIK, 1989, p.9).
} 
Segundo Neves (1997, p.20) "é importante observar que a relação entre a intenção do falante e a interpretação do destinatário é mediada, mas não estabelecida, pela expressão lingüística". Isto significa que para o destinatário, a interpretação se baseará somente em parte na informação que está contida na expressão linguística, e para o falante, a expressão linguística não precisa se constituir numa verbalização plena de sua intenção pragmática, ou seja, ao levar em conta a informação que o destinatário tem no momento da fala, o falante considera que uma verbalização parcial é suficiente.

Nesse sentido são várias as vantagens de se fazer uso tanto do modelo de interação verbal proposto por Dik (1989) quanto do jogo de imagens observado por Pêcheux (1969) para a análise dos discursos jurídicos. São evidentes as situações em que os advogados procuram efetuar mudanças na informação pragmática do corpo de jurados, ou quando procuram lembrar, adicionar ou substituir as informações deles. Tais situações são utilizadas pelos advogados como estratégias retórico-discursivas em suas tentativas de convencer/ persuadir ${ }^{4}$ seus ouvintes.

Sendo a linguagem instrumento da técnica jurídica, uma ferramenta de trabalho do advogado, faz-se necessário, então, considerar a função que desempenha cada orador ao fazer uso da palavra no tribunal. Podemos pensar numa sessão de tribunal do júri como uma peça de teatro, onde cada um fala a seu tempo, com prazo pré-determinado e exerce um papel, também previamente estabelecido, o qual irá demonstrar no decorrer da sessão.

A profissão de jurista tem sempre por norma a realização da justiça. A atuação dos advogados é de luta e o discurso do juiz caracteriza-se como autoritário. Mas todos são orientados a fazer uso das técnicas de falar e escrever corretamente. O Advogado de Defesa procura persuadir e convencer o auditório de que seu cliente é inocente e que o direito lhe assiste. O Advogado de Acusação tenta, por meio de seu discurso, convencer que a acusação por ele empreendida é a mais plausível de ser seguida no caso apreciado. Com um discurso por excelência autoritário, o Juiz pratica a dominação pela palavra. Ele utiliza-se de um discurso que Koch (1992) chama de exclusivista, pois não permite quaisquer mediações ou ponderações por parte do auditório. Sua missão consiste em impor o direito. Apesar de falarem de lugares diferentes, os discursos dos dois advogados constituem-se em um só tipo: discursos argumentativos, o que não se pode afirmar do discurso elaborado pelo Juiz.

Aplicando-se o modelo de interação verbal de Dik (1989), o jogo de imagens efetuado pelos advogados de defesa e de acusação e suas intenções pragmáticas pressupostas, é possível caracterizar e contextualizar os discursos e os interlocutores no contexto de interação das sessões de tribunal do júri.

\section{CONSIDERAÇÕES FINAIS}

Considerando que nossa pesquisa promoveu uma reflexão acerca das peculiaridades que envolvem o discurso proferido pelos juristas, é possível afirmar que há, ainda, outros fatores de importância na sua elaboração, entre os quais citamos a própria posição social dos depoentes (réu, testemunhas e vítima), acontecimentos diários na sociedade onde vivem os que ali estão e marcas fonológicas usadas em discursos orais, os quais podem se constituir em um recurso decisivo na organização geral do discurso jurídico.

Importa-nos mostrar que fatores como as peculiaridades do discurso jurídico, aqui descritas e transmitidas aos aspirantes a juristas ainda durante a graduação, compõem as condições de produção do discurso jurídico e constituem o processo de interação comunicativa dos tribunais, o que nos auxiliou a compor a reflexão proposta nesta pesquisa.

\footnotetext{
${ }^{4}$ A distinção entre Convencer (discurso dirigido à razão por meio de raciocínio lógico) e Persuadir (discurso de caráter ideológico, subjetivo e intemporal) é feita por Perelman e Olbrechts-Tyteca (2000).
} 


\section{REFERÊNCIAS}

ALLAN, D.J. A filosofia de Aristóteles. 2.ed. Tradução por Rui Gonçalo Amado. Lisboa: Presença, 1983. 199p.

BEZERRA, J.de R. M.. Análise do discurso: uma linguagem do poder judiciário. Curitiba: HD Livros, 1998. 208p.

CAHALI, Y. S. (Org.). Código civil. Código de processo civil. Constituição Federal. São Paulo: Revista dos Tribunais, 1999. 1169p.

CITELLI, A.. Linguagem e persuasão. São Paulo: Ática, 2004. 77p.

DAMIÃO, R. T.; HENRIQUES, A.. Curso de português jurídico. 3.ed. São Paulo: Atlas, 2015. 267p.

DIK, S. The theory of functional grammar. Pt. I: The Structure of the clause.DordrechtHolland/Providence RI-USA: Foris Publication, 1989. 433p.

The theory of functional grammar. Pt. II: Complex and derived constructions. New York: Mounton, 1997. 477p.

FAGUNDES, V.O.. O discurso no júri: aspectos lingüísticos e retóricos. São Paulo: Cortez, 1987. 136p.

GOMES, L.F.. (Org.) Código Penal. Código de processo penal. Constituição Federal. 4.ed. São Paulo: Revista dos Tribunais, 2002.

KOCH. I. G. V. A inter-ação pela linguagem. São Paulo: Contexto, 1992. 115p. (Coleção Repensando a Língua Portuguesa)

MARTINS, M.H. N. R. A.. Considerações acerca da linguagem forense. Revista Jurídica da Universidade de Franca. Franca, ano1, n.1, p.145-6, nov.1998.

NASCIMENTO, E. D. Linguagem forense: a língua portuguesa aplicada à linguagem do foro. 10.ed. São Paulo: Saraiva, 2013. 312 p.

NEVES, M. H. M. A gramática funcional. São Paulo: Martins Fontes, 1997. 160p.

OSAKABE, H. Argumentação e discurso político. São Paulo: Kairós, 1979. 200p.

PÊCHEUX, M.. Análise automática do discurso (1969). In: GADET, F.; HAK, T. (Orgs.). Por uma análise automática do discurso: uma introdução à obra de Michel Pêcheux. Tradução por Bethânia S. Mariani et al. Campinas: Unicamp, 1993 (Coleção Repertórios).

PERELMAN, C.; OLBRECHTS-TYTECA, L. Tratado da argumentação: a nova retórica. Tradução por Maria Ermantina Galvão Pereira. São Paulo: Martins Fontes, 2000. 653p.

PETRI, M. J.C.. Argumentação linguística e discurso jurídico. São Paulo: Selinunte, 2000. 136p. (Coleção Processos Expressivos da Linguagem)

REALE, M.. A temática geral e os temas especiais. In: Filosofia do direito. São Paulo: Saraiva, 1996. p.300-14.

RIBEIRO, A.C.. A literatura e o direito. Júris Poiesis - Revista dos cursos de Direito da Universidade Estácio de Sá, Rio de Janeiro, v.1, n.1, p.113-19, mar./jul.1999. 